\title{
Nitrogen fertilization for noble garlic production in high altitude regions of the Brazilian semiarid region
}

\section{Adubação nitrogenada para produção de alho nobre em regiões de altitude do semiárido brasileiro}

\section{Gabrielly Paula de Sousa Azevedo HENRIQUES ${ }^{1}$; Maria Zuleide de NEGREIROS ${ }^{1}$; Francisco Vilela RESENDE ${ }^{2}$; Welder de Araújo de Rangel LOPES ${ }^{1}$; Renan da Cruz PAULINO ${ }^{3}$}

\author{
${ }^{1}$ Doutorado, Centro de Ciências Agrárias, Universidade Federal Rural do Semi-Árido, UFERSA, Mossoró-RN, Brasil \\ ${ }^{2}$ Doutorado, Empresa Brasileira de Pesquisa Agropecuária, EMBRAPA, Brasília-DF, Brasil \\ ${ }^{3}$ Autor para corrrespondência, Doutorado, Departamento de Ciências Vegetais/ Centro de Ciências Agrárias, Universidade \\ Federal Rural do Semi-Árido, UFERSA, Mossoró-RN, Brasil, e-mail: renan@ufersa.edu.br
}

Recebido em: 27-07-2018; Aceito em: 07-10-2018

\begin{abstract}
Rio Grande do Norte State in Brazil has microregions with altitudes where the edaphoclimatic conditions are favorable to the cultivation of garlic, including vernalized noble garlic. An example is the municipality of Martins, where vegetable cropping is not a traditional practice. Since it is a region with potential for cultivation of noble garlic, comprising soil and climate conditions that are distinct from traditional production regions in Brazil, the use of nitrogen fertilization becomes an alternative to increase crop yield. This fact can stimulate the semiarid producer to invest in the crop, once it guarantees greater economic return. Thus, aiming to evaluate the production of vernalized noble garlic as a function of nitrogen doses applied in top dressing, an experiment was developed from May to August 2014, using a complete randomized complete block design with five replicates. The treatments consisted of the cover application of increasing doses of $\mathrm{N}\left(0,40,80,120\right.$, and $\left.160 \mathrm{~kg} \mathrm{ha}^{-1}\right)$. The following were evaluated: plant height; number of leaves; average bulb weight; total, commercial, and noncommercial bulb yield; bulb and bulblet classification; and number of bulblets per bulb. The dose of $90 \mathrm{~kg} \mathrm{ha}^{-1}$ nitrogen, applied in top dressing, provided the highest averages of plant height, number of leaves, average bulb weight, and total bulb yield. The dose of maximum economic efficiency was $91 \mathrm{~kg} \mathrm{ha}^{-1}$, which promoted greater commercial bulb yield. The number of bulblets per bulb and bulblet classification were not influenced by nitrogen doses applied in top dressing.
\end{abstract}

Additional keywords: Allium sativum L; nitrogen; refrigeration; yield.

\section{Resumo}

O Rio Grande do Norte possui microrregiões de altitudes, como o município de Martins, sem tradição de cultivo de hortaliças, com condições edafoclimáticas favoráveis ao cultivo de alho, inclusive para produção de cultivares nobres vernalizadas. Por ser uma região com potencial de cultivo de alho nobre com condições de clima e solo distintas das tradicionais regiões produtoras do Brasil, a adubação nitrogenada contribui para o aumento de produtividade dessa hortaliça, fato que pode estimular o produtor do semiárido a investir na cultura, pois garante maior retorno econômico. Desse modo, com o objetivo de avaliar a produção de alho nobre vernalizado em função de doses de nitrogênio em cobertura, foi desenvolvido um experimento de maio a agosto de 2014, utilizando o delineamento em blocos casualizados completos, com cinco repetições. Os tratamentos consistiram na aplicação em cobertura de doses crescentes de $\mathrm{N}\left(0,40,80,120\right.$, e $\left.160 \mathrm{~kg} \mathrm{ha}^{-1}\right)$. Foram avaliados altura de plantas, número de folhas, massa média de bulbos, produtividade total, comercial e não comercial de bulbos, classificação dos bulbos e de bulbilhos, e número de bulbilhos por bulbo. A dose de $90 \mathrm{~kg} \mathrm{ha}^{-1}$ de nitrogênio aplicado em cobertura proporcionou as maiores médias de altura de plantas, número de folhas, massa média de bulbos e produtividade total. A dose de máxima eficiência econômica foi a de $91 \mathrm{~kg} \mathrm{ha}^{-1}$, a qual promoveu maior produtividade comercial de bulbos. O número de bulbilhos por bulbo e a classificação de bulbilhos não foram influenciados pelas doses de nitrogênio em cobertura.

Palavras-chave adicionais: Allium sativum L; frigorificação; nitrogênio; produtividade.

\section{Introduction}

Garlic is a vegetable of great economic and social importance in Brazil, mainly because it is mostly grown by small farmers and requires large-scale labor force. Domestic garlic consumption in 2015 exceeded 300 thousand tons $(1.5 \mathrm{~kg} / \mathrm{inh}$ abitant/year), one of the largest consumptions in the world, and has been increasing systematically in recent years (ANAPA, 2016). Domestic production, which in 2015 was 
120,597 tons (IBGE, 2015), accounts for only a third of the country's consumption. However, in recent years, garlic production in Brazil has increased thanks to the development of new production technologies. In addition, more productive cultivars have entered the production system. These improvements have made it possible to expand the cultivation of this vegetable to new planting areas in some regions of the country.

To meet its domestic demand, Rio Grande do Norte imports garlic from other regions of Brazil and from China. Notwithstanding, the state has microregions with altitudes where the edaphoclimatic conditions are favorable to cultivation of garlic, including vernalized noble garlic. An example is the municipality of Martins, where vegetable cropping is not a traditional practice.

Regarding garlic mineral nutrition, most of the existing research relates to times when technology was quite limited, reflecting low yields. The emergence of vernalization technology allowed the cultivation of noble cultivars originating in the south of Brazil and Argentina, and in other regions of Brazil such as the southeast, midwest, and microregions of the northeast. Moreover, this technology has also made possible the use of virus-free bulblets for planting. Thus, there is a need to evaluate the yield performance of these materials regarding mineral nutrition in the different edaphoclimatic conditions (Souza et al., 2011).

Among the environmental factors responsible for increasing garlic yield stands out the application of chemical fertilizers, in particular nitrogen, since it is the nutrient most demanded by the plant, with a marked effect on crop growth and development (Macêdo et al., 2009; Fernandes et al., 2010).

Nitrogen is responsible for increasing garlic yield, although the response to the applied doses is quite variable. Such response depends, besides the cultivar health, on the amount of organic matter in the soil, on soil type, as well as on the methods and times of application of the nutrient doses used. Therefore, Resende et al. (2000), Lima et al. (2008), and Backes et al. (2008) verified an increasing quadratic behavior for total bulb yield, using doses up to $234 \mathrm{~kg} \mathrm{ha}^{-1}$, $150 \mathrm{~kg} \mathrm{ha}^{-1}$, and $268 \mathrm{~kg} \mathrm{ha}^{-1} \mathrm{~N}$, respectively. In turn, Macedo et al. (2009) and Fernandes et al. (2010) observed that total yield increased linearly, reaching a maximum value at doses of 180 and $320 \mathrm{~kg} \mathrm{ha}^{-1} \mathrm{~N}$, respectively. However, under field conditions, Lima et al. (2008) did not obtain a significant effect of $\mathrm{N}$ on total garlic yield when using doses up to $360 \mathrm{~kg} \mathrm{ha}^{-1}$. For this reason, nitrogen doses should not be standardized for maximum garlic yield in the different planting regions.

In view of the above, the present work evaluates the production of vernalized noble garlic as a function of nitrogen doses applied in top dressing, under the edaphoclimatic conditions of the Brazilian semiarid.

\section{Materials and methods}

The experiment was carried out from May to August 2014, in the municipality of Martins, located in the west region of Rio Grande do Norte. The experimental area is located at $6^{\circ} 4^{\prime} 59^{\prime \prime} S$ latitude, 37 $54^{\prime} 50^{\prime \prime}$ W longitude, at an altitude of $745 \mathrm{~m}$. According to Köppen's classification, the climate of the region is Aw, tropical rainy, with dry winter and rainy season until July. Average annual rain fall ranges between 800 and $1,200 \mathrm{~mm}$ (SEPLAN, 2013). During the development of the research, the minimum and maximum temperatures varied between 16.8 and $20.9{ }^{\circ} \mathrm{C}$ and 22.3 and $30.5^{\circ} \mathrm{C}$, respectively, with average temperature of 22.8 ${ }^{\circ} \mathrm{C}$ and relative air humidity of $66.5 \%$.

The soil was classified as clayey dystrophic Red Latosol (Embrapa 2013).Soil fertility analysis showed the following composition: $\mathrm{pH}\left(\mathrm{H}_{2} \mathrm{O}\right)=4.69$; $\mathrm{N}=0.20 \mathrm{~g} \mathrm{~kg}^{-1} ; \mathrm{P}=8.0 \mathrm{mg} \mathrm{dm}^{-3} ; \mathrm{K}=50.0 \mathrm{mg} \mathrm{dm}^{-3}$; $\mathrm{Na}=47.0 \mathrm{mg} \mathrm{dm}{ }^{-3} ; \mathrm{Ca}=0.94 \mathrm{cmol}_{\mathrm{c}} \mathrm{dm}^{-3} ; \mathrm{Mg}=$ $0.85 \mathrm{cmol}_{c} \mathrm{dm}^{-3} ; \mathrm{Al}=1.0 \mathrm{cmol}_{\mathrm{c}} \mathrm{dm}^{-3} ; \mathrm{H}+\mathrm{Al}=$ $6.11 \mathrm{cmol}_{\mathrm{c}} \mathrm{dm}^{-3} ; \quad \mathrm{SB}=2.02 \mathrm{cmol}_{\mathrm{c}} \mathrm{dm}^{-3} ; \mathrm{t}=$ $3.02 \mathrm{cmol}_{\mathrm{c}} \mathrm{dm}^{-3} ; \mathrm{CEC}=8.13 \mathrm{cmol}_{\mathrm{c}} \mathrm{dm}^{-3} ; \mathrm{V}=25 \% ; \mathrm{m}=$ $33 \%$; $\mathrm{ESP}=3 \%$; and $\mathrm{OM}=21.57 \mathrm{~g} \mathrm{~kg}^{-1}$. The elements $\mathrm{N}$ (Kjeldahl method), $\mathrm{P}, \mathrm{Na}^{+}$, and $\mathrm{K}^{+}$(Mehlich $^{-1}$ extractor), $\mathrm{Ca}^{2+}, \mathrm{Mg}^{2+}$, and $\mathrm{Al}^{3+}$ (extracted with $1 \mathrm{~mol} \mathrm{~L}^{-1}$ $\mathrm{KCl}), \mathrm{H}+\mathrm{Al}$ (extracted with $0.5 \mathrm{~mol} \mathrm{~L}^{-1}$ calcium acetate) were assessed according to Teixeira et al. (2017).

The experimental design was a randomized complete block with five replicates, and the treatments consisted of five nitrogen doses applied in top dressing: 0, 40, 80, 120, and $160 \mathrm{~kg} \mathrm{ha}^{-1}$.

The experimental plots were formed by flower beds of $0.20 \mathrm{~m}$ height, $1.25 \mathrm{~m}$ width, and $2.0 \mathrm{~m}$ length, containing five planting rows. The bulblets were planted at a depth of $0.05 \mathrm{~m}$, with spacing of $0.25 \mathrm{~m}$ between rows and $0.10 \mathrm{~m}$ between plants. The useful area of each plot was $1.35 \mathrm{~m}^{2}$, with 54 plants. It was represented by the three central rows, disregarding one plant at the ends of each row.

The cultivar used was "Jonas", which has round and large bulbs, with a white membrane and few bulblets showing a pink or purple film. It is a cultivar susceptible to superbudding, considered early, less demanding in photoperiod and temperature among noble garlic cultivars (Lucini, 2004), and therefore more suitable for the Brazilian northeast region.

Before planting, bulbs were subjected to vernalization in a cold chamber regulated at a temperature of $4^{\circ} \mathrm{C} \pm 1{ }^{\circ} \mathrm{C}$ and relative humidity of 65 to $70 \%$, for a period of 60 days. A sample was taken when the bulbs entered the cold chamber, from which the visual index of dormancy (VID) was determined. This index is given by the ratio between the length of the sprouting leaf and the length of the bulblet. Garlic cultivar "Jonas" had the recommended VID to start vernalization, between 30 and 40\% (Lucini, 2004). The bulbs were removed from the cold chamber one day before planting for threshing and treatment of bulblets with $2.5 \%$ iprodione solution to prevent a possible attack of soil microorganisms. 
Soil tillage consisted of plowing and harrowing, with later preparation of flower beds. Soil acidity was corrected at the time of such preparation, incorporating $700 \mathrm{~kg} \mathrm{ha}^{-1} \mathrm{Ca}(\mathrm{OH})_{2}$ (extinct lime) uniformly, 15 days before planting the bulblets. Planting fertilization was performed based on the soil analysis and suggestions from Cavalcanti (2008) and Resende et al. (2004), consisting of $30 \mathrm{~kg} \mathrm{ha}^{-1} \mathrm{~N}$ (calcium nitrate), $180 \mathrm{~kg} \mathrm{ha}^{-1}$ $\mathrm{P}_{2} \mathrm{O}_{5}$ (simple superphosphate), $40 \mathrm{~kg} \mathrm{ha}^{-1} \mathrm{~K}_{2} \mathrm{O}$ (potassium chloride), $150 \mathrm{~kg} \mathrm{ha}^{-1} \mathrm{Mg}$ (magnesium sulphate), $12 \mathrm{~kg} \mathrm{ha}^{-1} \mathrm{Zn}$ (zinc sulphate), and $1.7 \mathrm{~kg} \mathrm{ha}^{-1} \mathrm{~B}$ (boric acid). Nitrogen fertilization in top dressing was performed considering the doses recommended in the treatments $\left(0,40,80,120\right.$, and $\left.160 \mathrm{~kg} \mathrm{ha}^{-1}\right)$, being carried out at 20 and 60 days after planting, distributing, respectively, $20 \%$ and $80 \%$ of the dose, using urea as $\mathrm{N}$ source.

Microsprinkler irrigation was applied (flow rate of $27 \mathrm{~L} \mathrm{~h}^{-1}$ per microsprinkler), at a pressure of 200 $\mathrm{kPa}$, with two microsprinklers distributed in each plot. Tensiometers were installed at 0.15 and $0.30 \mathrm{~m}$ depth with two replicates, to monitor soil moisture during the crop cycle. Irrigation was suspended three days before harvest.

Weeding was carried out throughout the crop cycle to keep the plant environment clean. In addition, 30 days after planting (DAP), products based on mancozeb (2.5 $\left.\mathrm{g} \mathrm{L}^{-1}\right)$ and iprodione $\left(1.5 \mathrm{~mL} \mathrm{~L}^{-1}\right)$ were sprayed at seven-day intervals aiming toprevent and control rust and purple spot. For the control of thrips and mites, chlorfernapyr-based products $\left(0.5 \mathrm{~mL} \mathrm{~L}^{-1}\right)$ were sprayed at fifteen-day intervals.

Harvesting was performed when plants showed signs of maturation, identified by yellowing and partial drying and/or tipping of shoots. After harvesting, the plants were sun-cured for three days. This process consisted of distributing the plants in such a way that the leaves covered the bulbs of other plants, protecting them from sunrays. Subsequently, shade curing was carried out for a period of 17 days in a shady, dry, and ventilated place. After curing, the bulbs were cleaned by removing dry and dirty roots, leaves, and membranes.

The following characteristics were evaluated in the field: Plant height $(\mathrm{cm})$ - measured by the distance between the soil level and the end of the highest leaf, quantified in a sample of ten plants from each plot, at $30,45,60$, and 75 DAP; Number of leaves - determined by counting green leaves from a sample of ten plants from the useful area of each plot, at 30, 45, 60, and 75 DAP.

After curing and cleaning, the following characteristics were evaluated: Average bulb weight $(\mathrm{g})$ ratio between the weight and total number of bulbs; Bulb classification according to the transverse diameter (Ordinance No. 242 of 09/17/1992; MAPA): class 3 (greater than $32 \mathrm{~mm}$ up to $37 \mathrm{~mm}$ ), class 4 (greater than $37 \mathrm{~mm}$ up to $42 \mathrm{~mm}$ ), class 5 (greater than $42 \mathrm{~mm}$ up to $47 \mathrm{~mm}$ ), class 6 (greater than $47 \mathrm{~mm}$ up to $56 \mathrm{~mm}$ ), and class 7 (greater than $56 \mathrm{~mm}$ ); Total bulb yield $\left(\mathrm{t} \mathrm{ha}{ }^{-1}\right)$ - weighing of commercial and noncommercial bulbs from the useful area of each plot;
Commercial bulb yield ( $\mathrm{t} \mathrm{ha}^{-1}$ ) - sum of bulbs of classes 3 to 7 (the bulbs of each class were weighed, and the data expressed as a percentage of each class in relation to total bulb production); Noncommercial bulb yield (t ha-1) - weighing of bulbs with transverse diameter less than $32 \mathrm{~mm}$; Number of bulblets per bulb - ratio between the number of bulblets and the total number of bulbs; Bulblet classification - carried out by means of four sieves: large bulblets, retained in sieve 1 (15 $\times 25 \mathrm{~mm}$ mesh), medium-sized, retained in sieve 2 (10 x $20 \mathrm{~mm}$ mesh), medium-small, retained in sieve 3 (8 x $17 \mathrm{~mm}$ mesh), small, retained in sieve 4 (5 $\mathrm{x}$ $17 \mathrm{~mm}$ mesh), and very small or "sticks", which pass through sieve 4.

For the analysis of variance and regression analysis, softwares Sisvar® (Ferreira, 2008) and Table Curve 2D v.5.01 (Jandel Scientific, 1991) were used at $5 \%$ probability level. For plant height and number of leaves, statistical analysis was performed according to a complete randomized block design with four replicates, in split-plots. The plots were represented by the nitrogen doses applied in coverage, and the subplots by the evaluation times.

Based on the commercial bulb yield value estimated by the regression equation model, the dose of maximum economic efficiency was calculated by gross (GR) and net revenue (NR) and fertilizer costs, which varied according to the doses and the price of garlic. The other costs were not considered, being the same for all treatments. Gross revenue (GR) was calculated considering the production estimated by the fitted regression equation model and the price of bulbs in August 2014 at supply centers of Rio Grande do Norte -CEASA (1 kg was quoted at $R \$$ 9.35). Net revenue (NR), in turn, was calculated by subtracting the cost of fertilizers from GR.

Thus, the economic study of polynomial functions was performed following the methodology used by Silva et al. (2014): NR = GR - FC - VC, where NR is the net revenue or profit of an agricultural crop; $\mathrm{GR}=\mathrm{Y} . \mathrm{w}$, wherein $\mathrm{Y}(\mathrm{kg})$ is the quantity of product and w $(R \$ / \mathrm{kg})$ is the price of that product; fixed charge $(F C)=m$; variable charge $(V C)=t . X$, where $t(R \$ / \mathrm{kg})$ is the input price and $X(\mathrm{~kg}$ of $\mathrm{N})$ is the input quantity.

\section{Results and discussion}

There was a significant effect of the interaction between nitrogen doses and evaluation times for plant height $(\mathrm{PH})$ and number of leaves (NL). Nitrogen doses also had a significant effect on average bulb weight (ABW), total bulb yield (TBY), commercial bulb yield (CBY), noncommercial bulb yield (NBY), and bulb classification. There was no effect of nitrogen doses on the number of bulblets per bulb (NBB) and bulblet classification.

There was a quadratic effect for plant height as a function of evaluation times for each nitrogen dose. The maximum estimated values were $41.23 \mathrm{~cm}$, at 64 DAP; $46.78 \mathrm{~cm}$, at $60 \mathrm{DAP} ; 61.13 \mathrm{~cm}$, at 63 DAP; $54.01 \mathrm{~cm}$, at $65 \mathrm{DAP}$; and $44.03 \mathrm{~cm}$, at $61 \mathrm{DAP}$, at doses of $0,40,80,120$, and $160 \mathrm{~kg} \mathrm{ha}^{-1} \mathrm{~N}$, respectively (Figure 1A). Souza et al. (2011), working with the cultivar "Roxo Pérola de Caçador" in Lavras, MG, also 
verified a quadratic effect for plant height as a function of evaluation times, obtaining maximum height $(81.1 \mathrm{~cm})$ at 100 DAP. This quadratic behavior, observed in both studies, can be attributed to shoot

A

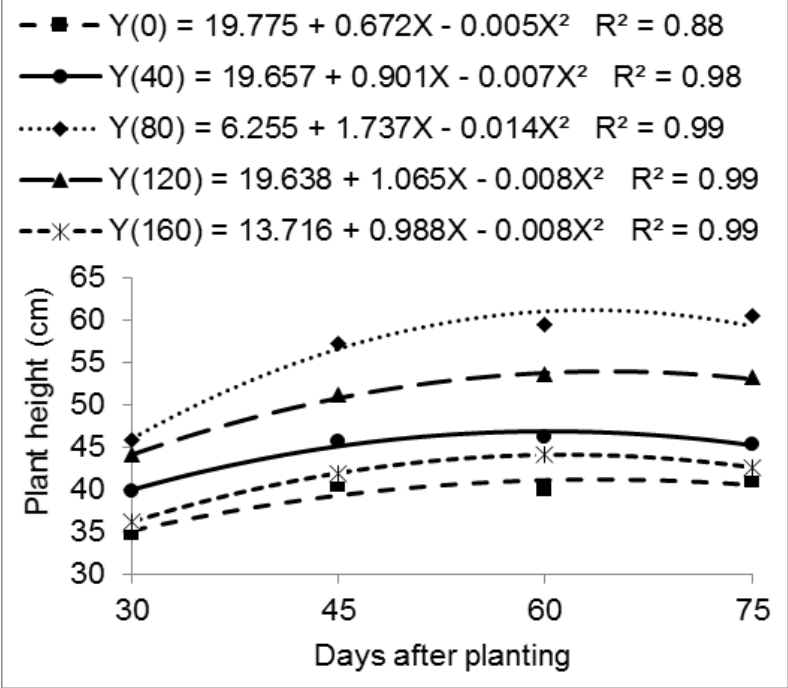

senescence, indicating that during bulbification, a large part of leaf photoassimilates is redistributed to the bulbs.
B

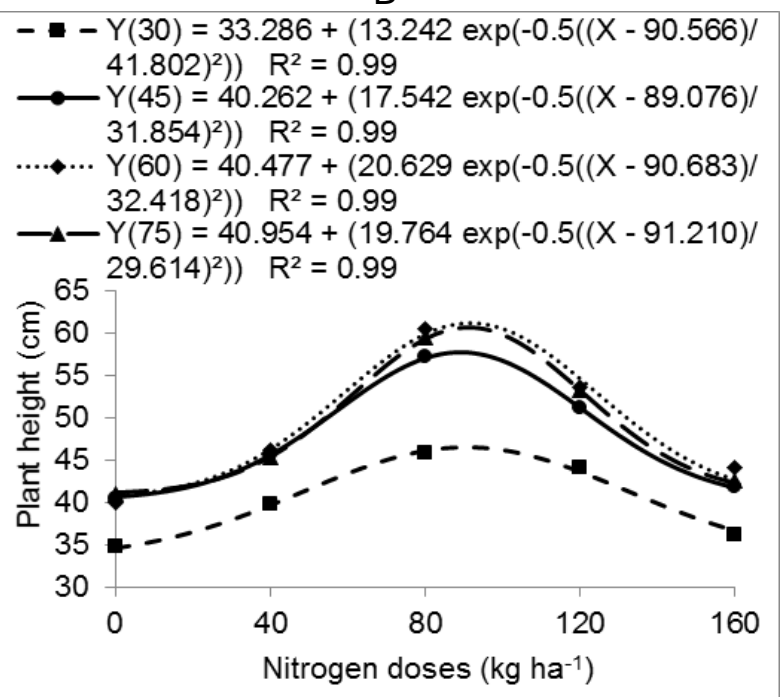

Figure 1 - Height of garlic plants as a function of the evaluation period for each nitrogen dose $(0,40,80,120$ and $\left.160 \mathrm{~kg} \mathrm{ha}^{-1}\right)$ under cover $(A)$. Height of garlic plants as a function of nitrogen doses in top dressing $(30,45,60$ and 75 days after planting - DAP) (B).

Analyzing plant height as a function of nitrogen doses in each evaluation time, it was observed that the highest averages estimated for plant height were 46.53; 57.80; 61.11 ; and $60.72 \mathrm{~cm}$, obtained at nitrogen doses $90.56 \mathrm{~kg} \mathrm{ha}^{-1}$ (30 DAP); $89.07 \mathrm{~kg} \mathrm{ha}^{-1}$ (45 DAP); $90.68 \mathrm{~kg} \mathrm{ha}^{-1}$ (60 DAP); and $91.21 \mathrm{~kg} \mathrm{ha}^{-1}$ (75 DAP), respectively (Figure 1B). It can be seen, therefore, that doses close to $90.0 \mathrm{~kg} \mathrm{ha}^{-1} \mathrm{~N}$ provided the highest plant heights, regardless of evaluation time.

When analyzing the effect of evaluation times for each nitrogen dose, no significant difference was observed for the number of leaves at doses of 0 and
$160 \mathrm{~kg} \mathrm{ha}^{-1}$, reaching averages of 5.1 and 5.3 , respectively. In contrast, there was an effect of evaluation times for the number of leaves at doses of 40,80 , and $120 \mathrm{~kg} \mathrm{ha}^{-1} \mathrm{~N}$, behaving quadratically, with estimated maximum of 6.0; 7.0; and 6.9 leaves at 75 DAP; respectively (Figure 2A). Souza et al. (2011) also verified a quadratic effect of the number of leaves as a function of evaluation times $(30,50,70,90,110$, and $130 \mathrm{DAP}$ ), but reaching a maximum of 7.3 leaves at 81 DAP, probably due to the longer cycle presented by the cultivar "Roxo Pérola de Caçador" under the cultivation conditions.
A

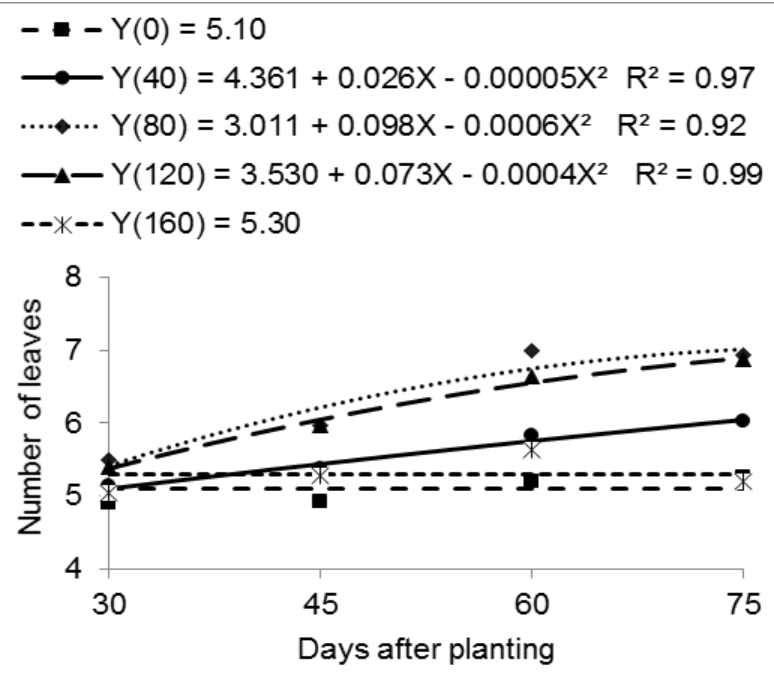

$\mathrm{B}$

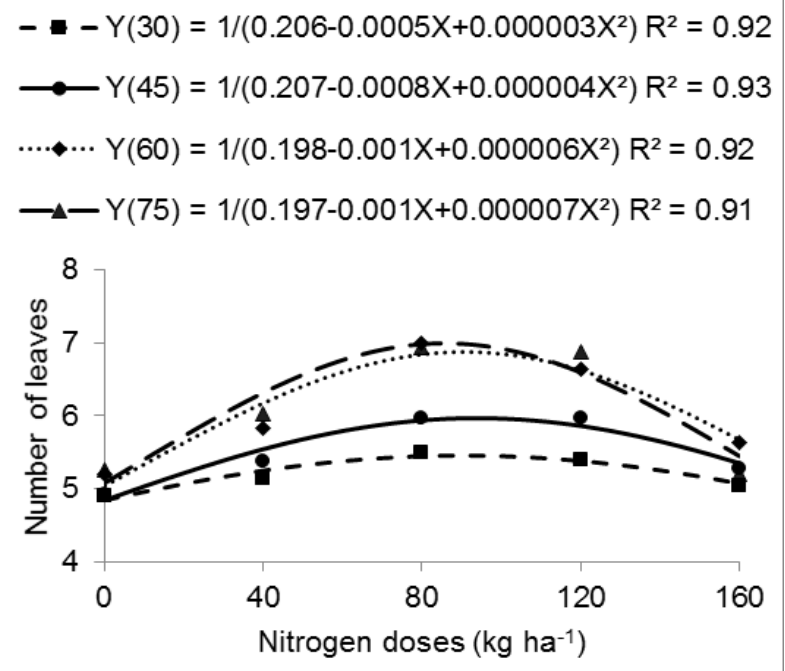

Figure 2 - Number of leaves per garlic plant as a function of the evaluation period for each nitrogen dose $(0,40$, 80,120 and $160 \mathrm{~kg} \mathrm{ha}^{-1}$ ) in cover (A). Number of leaves per garlic plant according to the doses of nitrogen under cover $(30,45,60$ and 75 days after planting - DAP) (B). 
When analyzing nitrogen doses as a function of evaluation times, maximum values of 5.5 leaves were observed at the dose of $90.21 \mathrm{~kg} \mathrm{ha}^{-1} ; 5.9$ leaves at $93.82 \mathrm{~kg} \mathrm{ha}^{-1} ; 6.9$ leaves at $90.66 \mathrm{~kg} \mathrm{ha}^{-1}$; and 6.9 leaves at $85.66 \mathrm{~kg} \mathrm{ha}^{-1}$, at 30, 45, 60, and 75 DAP, respectively (Figure $2 \mathrm{~B}$ ). In the same way as for height, doses close to $90 \mathrm{~kg} \mathrm{ha}^{-1}$ promoted a greater number of leaves at all evaluation times. Resende et al. (2000), using the seminoble garlic cv. "Gigante Roxão", in Marília-SP, verified an increase in the number of leaves with increasing nitrogen doses ( 0 to $\left.250 \mathrm{~kg} \mathrm{ha}^{-1}\right)$.

Average bulb weight (ABW) increased as a function of nitrogen doses up to the estimated maximum of $22.84 \mathrm{~g}$ at the dose of $90.35 \mathrm{~kg} \mathrm{ha}^{-1}$ (Figure 3). The increase of $A B W$ may be related to plant height and number of leaves, which presented a similar behavior, increasing up to the dose of approximately 90 $\mathrm{kg} \mathrm{ha}^{-1}$, providing a larger leaf area and, consequently, greater photoassimilate production for bulb growth. Doses greater than $90 \mathrm{~kg} \mathrm{ha}^{-1}$ negatively influenced these characteristics. Backes et al. (2008), evaluating nitrogen doses for cv. "Roxo Pérola de Caçador", in Santa Juliana-MG, observed a quadratic effect, with maximum average bulb weight $(36 \mathrm{~g})$ at the dose of $268 \mathrm{~kg} \mathrm{ha}^{-1}$. On the other hand, Macêdo et al. (2009) did not observe variation regarding average bulb weight for cV. "Roxo Pérola de Caçador", in LavrasMG. Average bulb weight is a fundamental feature for the commercialization of garlic, since the largest bulbs receive the best commercial prices, especially in more demanding markets (Resende \& Souza, 2001a).

The highest values of total bulb yield (6.87 $\left.\mathrm{t} \mathrm{ha}^{-1}\right)$ and commercial bulb yield $(6.78 \mathrm{t} \mathrm{ha-1}$ ) were obtained at the estimated doses of $90.34 \mathrm{~kg} \mathrm{ha}^{-1}$ and $91.04 \mathrm{~kg} \mathrm{ha}^{-1}$, respectively (Figure 4A). It is noteworthy that garlic yield increased until a maximum

A

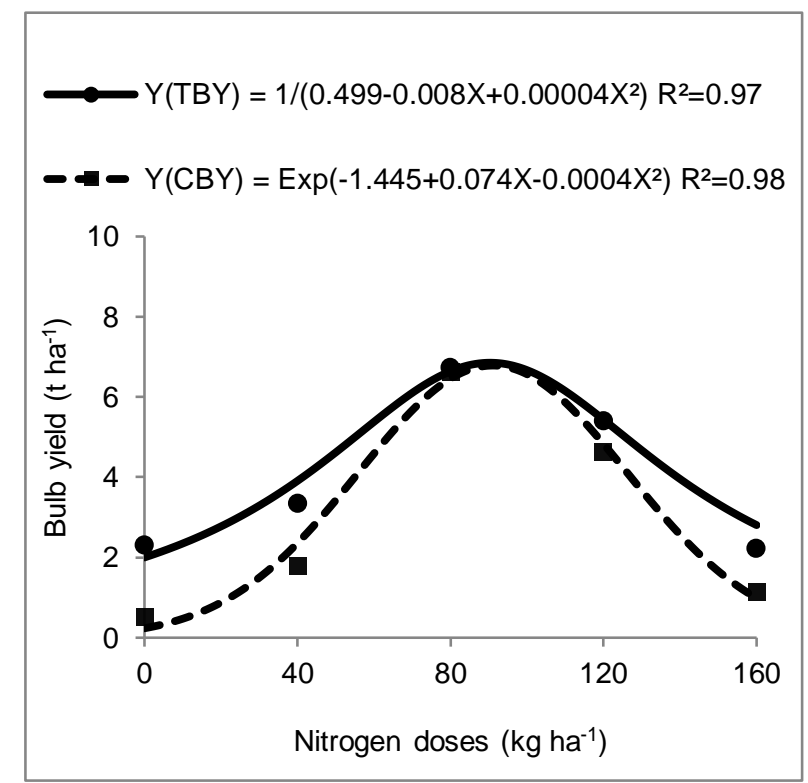

point with the increase of nitrogen doses applied in top dressing, reducing significantly with higher doses of the nutrient. This behavior, also observed for height, number of leaves, and average bulb weight, resulted in decreases in total and commercial yield. Excess application of nitrogen fertilizer in top dressing possibly led to osmotic stress and nutritional imbalance in the plant, affecting its growth and development. Attention should be also given to the plant's possible energy demand to perform osmotic adjustment and to absorb water and nutrients, which could be converted into production (Taiz \& Zeiger, 2013).

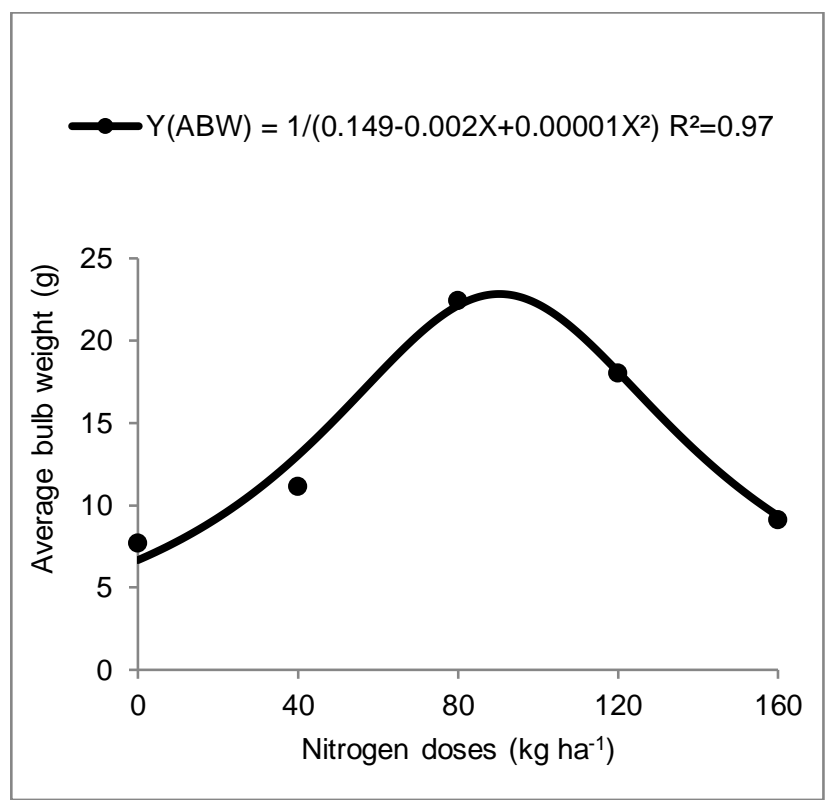

Figure 3 - Average bulb weight as a function of top dressing nitrogen doses.

B

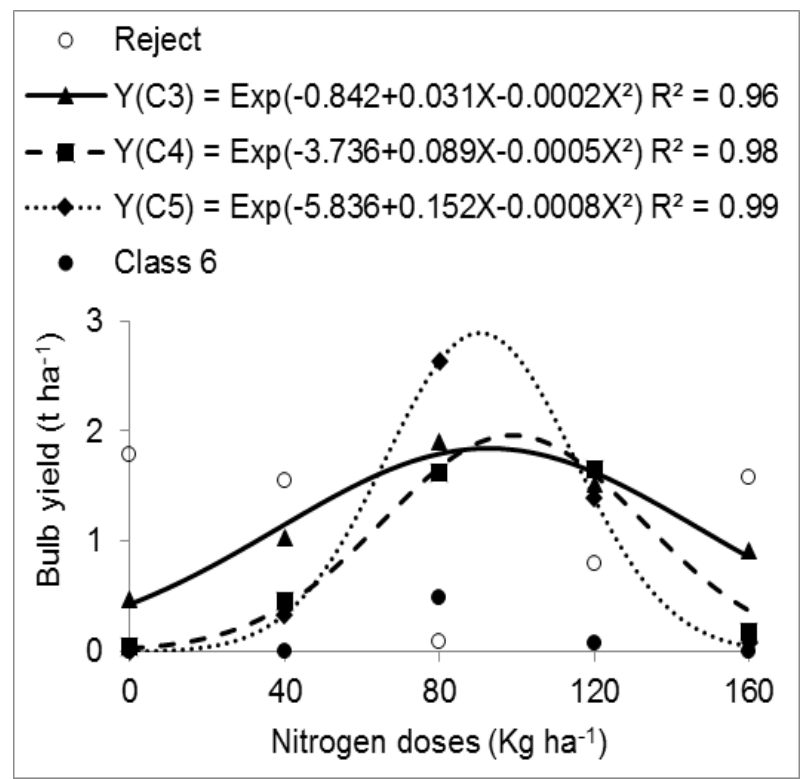

Figure 4 - Total (TBY) and commercial (CBY) bulb yield (A) and bulb yield per class (B) as a function of nitrogen doses applied in top dressing. 
Cavalcanti (2008) proposes the application of $30 \mathrm{~kg} \mathrm{ha}^{-1}$ nitrogen in planting fertilization, as was done in the present experiment, and $60 \mathrm{~kg} \mathrm{ha}^{-1}$ in top dressing (two-split application) for an expected yield of $5.5 \mathrm{t} \mathrm{ha}^{-1}$. However, in our study, it was possible to obtain a higher total yield $\left(6.87 \mathrm{t} \mathrm{ha}^{-1}\right)$ with a higher nitrogen dose applied in top dressing $\left(90.34 \mathrm{t} \mathrm{ha}^{-1}\right)$.

The yield performance of garlic in response to nitrogen fertilization in top dressing found in the present research and recorded in the literature is quite variable. It depends, besides the cultivar and edaphoclimatic conditions, on bulblet quality, on the planting system (field or greenhouse conditions), and on the levels, sources, and times of application of the nutrient doses used.

Resende \& Souza (2001b), evaluating nitrogen doses for the cultivar "Quitéria", verified a quadratic effect on total yield, with an estimated maximum of $6.6 \mathrm{t} \mathrm{ha}^{-1}$ at the dose of $149.2 \mathrm{~kg} \mathrm{ha}^{-1}$. In contrast, the authors found a linear decreasing effect on commercial yield. Fernandes et al., testing nitrogen doses applied in top dressing $\left(0,20,40,80,160\right.$, and $\left.320 \mathrm{~kg} \mathrm{ha}^{-1}\right)$ for the cultivar "Caçador LV" in a protected environment, showed an increasing linear effect on total and commercial yield, with estimated maximum values of 9.1 and $9.0 \mathrm{t} \mathrm{ha}^{-1}$, respectively. On the other hand, under field conditions, Lima et al. (2008) did not observe a significant effect of nitrogen doses $(0,20$, $40,60,120,240$, and $360 \mathrm{~kg} \mathrm{ha}^{-1}$ ) on total bulb yield. In a protected environment, however, the authors observed a quadratic response, obtaining the highest total yield $\left(5.5 \mathrm{t} \mathrm{ha}^{-1}\right)$ with the estimated dose of $150 \mathrm{~kg} \mathrm{ha}^{-1}$. Therefore, the diversity of nitrogen responses in the literature shows the need to establish absorption curves for nitrogen and other nutrients, and to perform a growth analysis for virus-free, vernalized seminoble garlic in the semiarid.

Regarding bulb classification, there was no fitted response curve for the behavior of noncommercial bulbs (class $<3$ - bulbs with transverse diameter less than $32 \mathrm{~mm}$ - or rejects) and class 6 bulbs (bulbs with transverse diameter greater than $47 \mathrm{~mm}$ up to $56 \mathrm{~mm}$ ) as a function of nitrogen doses (Figure 4B). Notwithstanding, by means of the observed data, it was found that the dose of $80 \mathrm{~kg} \mathrm{ha}^{-1}$ led to the lowest yield of reject garlic $\left(0.08 \mathrm{tha}^{-1}\right)$ and the highest yield of class 6 garlic $\left(0.48 \mathrm{t} \mathrm{ha}^{-1}\right)$. The less the number of class $<3$ or reject garlic, the more advantage for the producer, since these have no commercial value.

Class 3 garlic (bulb transverse diameter greater than $32 \mathrm{~mm}$ up to $37 \mathrm{~mm}$ ) reached an estimated maximum yield of $1.84 \mathrm{t} \mathrm{ha}^{-1}$ at the dose of $92.77 \mathrm{t} \mathrm{ha}^{-1} \mathrm{~N}$, while class 4 garlic (bulb transverse diameter greater than $37 \mathrm{~mm}$ up to $42 \mathrm{~mm}$ ) had the maximum estimated yield of $1.96 \mathrm{tha}^{-1}$ at the dose of $98.98 \mathrm{t} \mathrm{ha}^{-1} \mathrm{~N}$, and class 5 garlic (bulb transverse diameter greater than $42 \mathrm{~mm}$ up to $47 \mathrm{~mm}$ ) reached a maximum yield of $2.90 \mathrm{t} \mathrm{ha}^{-1}$ at the dose of $90.57 \mathrm{t} \mathrm{ha}^{-1}$ $\mathrm{N}$ (Figure 4B). Class 5 bulbs were the main responsible for obtaining higher yield at the estimated dose of
$90 \mathrm{~kg} \mathrm{ha}^{-1} \mathrm{~N}$, since they have a larger mass and diameter. They provide greater economic return to the producer, since larger bulbs have higher commercial value. Backes et al. (2008) observed that increased nitrogen doses promoted an increased percentage of class 5 bulbs and reduction of class 3 bulbs. Lima et al. (2008) did not verify effect of nitrogen doses on garlic classes.

The number of bulblets per bulb was not influenced by nitrogen doses, with an average of 8.12 (data not shown). This is a characteristic intrinsic to each cultivar, thus not influenced by the treatments. Moreover, the main factors influencing bulblet differentiation are photoperiod and temperature (Macêdo et al., 2009). In this case, the treatments were subjected to the same growing environment.

Likewise, bulblet classification was not influenced by nitrogen doses. However, it is worth mentioning that for all treatments, most of the bulblets were retained in sieve 4, followed by sieves 3,2 and 1 , with averages of $54.3 \%, 35.9 \%, 9.3 \%$, and $0.5 \%$, respectively.

Regression analyses of the type $y_{P E M}=e^{\hat{b}_{0}+\hat{b}_{1} X+\hat{b}_{2} x^{2}}$, found for commercial bulb yield, were derived to find the nitrogen dose of maximum physical efficiency:

$$
\begin{aligned}
x_{P E M D}= & \frac{d y}{d x}=0, \text { that is: } e^{\hat{b}_{0}+\hat{b}_{1} x+\hat{b}_{2} x^{2}}=0 \rightarrow \\
x_{P E M D}= & \frac{\hat{b}_{1}}{-2\left(\hat{b}_{2}\right)} \text { (Figure 5). }
\end{aligned}
$$

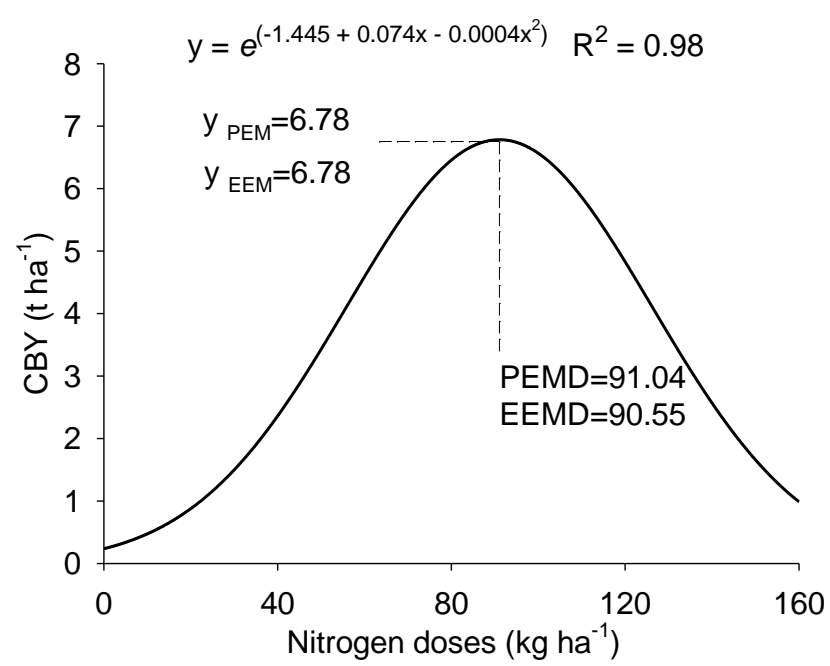

Figure 5 - Physical (PEMD) and economic efficiency maximum dose (EEMD) as a function of nitrogen doses applied in top dressing.

Thus, in equation:

$y_{P E M}=e^{\left(-1.445+0.074-0.0004 x^{2}\right)} \rightarrow$ 


$$
x_{P E M D}=\frac{0.073811}{-2(-0.000405)} \Rightarrow x_{P E M D}=91.04 \mathrm{~kg} \mathrm{ha}^{-1}
$$

$N$. For this value of $x_{P E M D}$, the corresponding value of $\mathrm{y}$ is: $y_{P E M}=e^{\left(-1.445+0.074-0.0004(91.04)^{2}\right)} \Rightarrow y_{P E M}=$ $6.78 \mathrm{t} \mathrm{ha}^{-1}$ bulbs. $\mathrm{RL}=\mathrm{Yw}-\mathrm{m}-\mathrm{tX}$ should be maximized. This is done by $\frac{d R L}{d x}=\left(\frac{d y}{d x}\right) w-t=0$, which implies $\left(\frac{d y}{d x}\right)=\frac{w}{t}$. Thus, with $y=e^{\hat{b}_{0}+\hat{b}_{1} X+\hat{b}_{2} X^{2}}$, then $\left(\frac{\mathrm{d} y}{\mathrm{dx}}\right)=\frac{\hat{b}_{1}}{-2\left(\hat{b}_{2}\right)}$ and $\frac{\hat{b}_{1}}{-2\left(\hat{b}_{2}\right)}=\frac{t}{w}$; by isolating $\mathrm{x}$, we have $x_{E E M D}=\frac{t / w-\hat{b}_{1}}{\hat{b}_{2}}$, in which the $t / w$ ratio varies as a function of product $(\mathrm{w})$ and input $(\mathrm{t})$ prices.

$x_{\text {EEMD }}=\frac{(3.82 / 9,500)-0.0738}{-0.000405} \Rightarrow x_{\text {EEMD }}=$

$=90.55 \mathrm{~kg} \mathrm{ha}^{-1} \mathrm{~N}$

$$
y_{E E M}=\boldsymbol{e}^{\left(-1.445+0.074-0.0004(90.55)^{2}\right)} \Rightarrow y_{E E M}=
$$$$
=6.78 \mathrm{t} \mathrm{ha}^{-1} \text { bulbs; }
$$

In this case, the dose of maximum economic efficiency (90.55 kg ha-1) was very close to that of maximum physical efficiency $\left(91.04 \mathrm{~kg} \mathrm{ha}^{-1}\right)$, both providing a commercial yield of $6.78 \mathrm{ha}^{-1}$. Thus, the producer will have maximum production and lower expenditure with fertilizers. However, this is not always the case, as found by Backes et al. (2008), who verified maximum yield of garlic bulbs at the dose of 268 $\mathrm{kg} \mathrm{ha}^{-1}$ nitrogen, although the dose for greater economic efficiency was $237 \mathrm{~kg} \mathrm{ha}^{-1}$.

\section{Conclusions}

The dose of $90 \mathrm{~kg} \mathrm{ha}^{-1}$ nitrogen applied in top dressing provided the highest averages of plant height, number of leaves, average bulb weight, and total yield.

The dose of maximum economic efficiency was $91 \mathrm{~kg} \mathrm{ha}^{-1}$, which promoted higher commercial bulb yield $\left(6.78 \mathrm{t} \mathrm{ha}^{-1}\right)$.

The number of bulblets per bulb and bulblet classification were not influenced by nitrogen doses applied in top dressing.

\section{Acknowledgements}

To the National Council of Scientific and Technological Development (CNPq) for granting financial support to the research.

\section{References}

ANAPA (2016) Associação Nacional dos Produtores de Alho. Edição Especial. Nosso Alho, n. 25, p. 13-16.

Backes C, Lima CP, Godoy LJG, Villas Boas RL, Imaizumi L (2008) Coloração verde nas folhas da cultura do alho vernalizado em respostas à adubação nitrogenada. Bragantia 67(2):491-498. http://dx.doi.org/10.1590/S0006-87052008000200025

Teixeira PC, Donagemma GK, Fontana A, Teixeira WG (Eds) (2017) Manual de métodos de análise de solo: 3.ed.rev. e ampl, Brasília, DF: Embrapa. 573 p.

Cavalcanti FJA (2008) Recomendações de adubação para o estado de Pernambuco: 2a aproximação. Recife, Instituto Agronômico de Pernambuco. 198p.

Embrapa (2013) Empresa Brasileira de Pesquisa Agropecuária. Sistema brasileiro de classificação de solos, Brasília. 353p.

Fernandes LJC, Büll LT, Corrêa JC, Pavan MA, Imaizumi I (2010) Resposta de plantas de alho livres de vírus ao nitrogênio em ambiente protegido. Horticultura Brasileira 28(1):97-101. http://dx.doi.org/10.1590/S0102-05362010000100018

Ferreira DF (2008) SISVAR: um programa para análises e ensino de estatística. Revista Symposium, 6:36-41.

IBGE. (2015) - Produção Agrícola Municipal. Culturas Temporárias e Permanentes. Disponível em: <ftp://ftp.ibge.gov.br/Producao_Agricola/Producao_Agric ola_Municipal_[anual]/2015/tabelas_pdf/tabela01.pdf $>$. Acesso em $18 \mathrm{dez} .2017$

Jandel Scientific (1991) Table Curve: curve fitting software. Corte Madera: Jandel Scientific. 280p.

Lima CP, Büll LT, Backes C, Godoy LJG, Kiil TAM (2008) Produtividade e características comerciais do alho vernalizado em função de doses de nitrogênio. Científica 36(1):48-55.

Lucini MA (2004) Manual Prático de Produção, Alho. Curitibanos, Bayer CropScience. 140p.

Macêdo FS, Silva RJ, Silva EC (2009) Exigências climáticas. In: Souza RJ, Macêdo FS (eds) Cultura do alho-Tecnologias modernas de produção, Lavras: UFLA. p.31-38.

Macêdo FS, Souza RJ, Carvalho JG, Santos BR, Reis LVR (2009) Produtividade de alho vernalizado em função de doses de nitrogênio e molibdênio. Bragantia 68(3):657-663. http://dx.doi.org/10.1590/S000687052009000300012 
MAPA (1992) Ministério da Agricultura, Pecuária e Abastecimento. Portaria № 242 de 17/09/1992. <http://www.codapar.pr.gov.br/arquivos/File/pdf/alho24 2_92.pdf>. Acesso em 19 de set. 2015

Resende FV, Oliveira PSR, Souza RJ (2000) Crescimento, produção e absorção de nitrogênio do alho proveniente de cultura de tecidos, cultivado com doses elevadas de nitrogênio. Horticultura Brasileira 18(1):3136. http://dx.doi.org/10.1590/S010205362000000100007

Resende FV, Dusi AN, Melo WF (2004) Recomendações básicas para a produção de alho em pequenas propriedades. Embrapa-CNPH, Brasília. 12p. (Comunicado técnico, 22)

Resende GM, Souza RJ (2001a) Doses e épocas de aplicação de nitrogênio sobre a produtividade e características comerciais de alho. Horticultura Brasileira 19(2):126-129. http://dx.doi.org/10.1590/S010205362001000200006
Resende GM, Souza RJ (2001b) Efeitos de tipos de bulbos e adubação nitrogenada sobre a produtividade e características comerciais do alho CV. "Quitéria". Horticultura Brasileira 19(3):188-191. http://dx.doi.org/10.1590/S0102-05362001000300005 SEPLAN (2013) Secretaria de Estado do Planejamento e das Finanças do Rio Grande do Norte. Perfil do Rio Grande do Norte. Natal, SEPLAN. 191p.

Silva FS, Oliveira FHT, Pereira RG, Silva PSL, Diógenes TBA, Silva ARC (2014) Doses de nitrogênio e fósforo para produção econômica de milho na Chapada do Apodi, RN. Revista Brasileira de Engenharia Agrícola e Ambiental 18(12):1247-1254. http://dx.doi.org/10.1590/1807-1929

Souza RJ, Macedo FS, Carvalho JG, Santos BR, Leite LVR (2011) Absorção de nutrientes em alho vernalizado proveniente de cultura de meristemas cultivado sob doses de nitrogênio. Horticultura Brasileira 29(4):498-503. http://dx.doi.org/10.1590/S010205362011000400009

Taiz L, Zeiger E (2013) Fisiologia Vegetal. Porto Alegre, Artmed. 918p. 